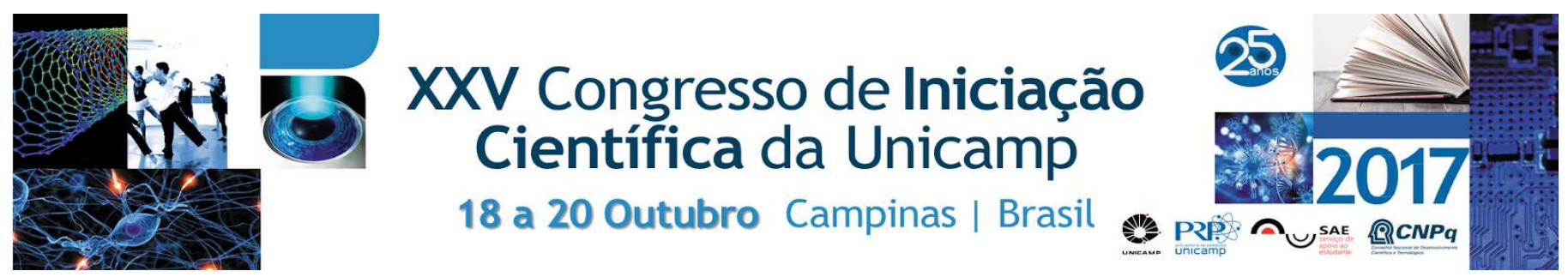

\title{
O CONHECIMENTO GEOGRÁFICO NA IDADE MÉDIA E NO RENASCIMENTO. AS TRANSFORMAÇÕES METODOLÓGICAS E EPISTEMOLÓGICAS SOBRE A NATUREZA NOS SÉCULOS XII E XVI E O SEU PAPEL NA CONCEPÇÃO DE GEOGRAFIA
}

\section{Damião S. Santos*}

\section{Resumo}

Entre os séculos XII e XIII há acontecimentos históricos, como surgimento da burguesia, Revolução Comercial e Industrial, e a criação de Universidades, surgindo nestas uma metodologia científica experimental matemática. Já entre os séculos XIV e XVI ocorre o Renascimento Cultural, onde é desenvolvido um conhecimento técnico científico experimental. A partir disso, o trabalho tem como objetivo investigar a transformação da mentalidade intelectual científica nos períodos referidos, em relação a concepção geográfica de natureza mundo.

\section{Palavras-chave:}

Renascimento, Ciência, Cartografia

\section{Introdução}

Entre os séculos XII e XIII há o ressurgimento de uma vida comercial urbana nas cidades medievais, devido o nascimento da burguesia mercantil, com a influência desta ocorreram a Revolução Comercial e Industrial, e a criação das universidades seculares, pensamento livre, surgindo uma metodologia científica experimental matemática, devido à influência das traduções das obras da Antiguidade greco-romana introduzidas pelos árabes. Em razão desses acontecimentos entre os século XIV e XVI acontece o Renascimento Cultural, onde é desenvolvido um conhecimento técnico científico experimental. A partir disso, o trabalho tem como objetivo investigar as transformações da mentalidade intelectual científica renascentista em relação a concepção geográfica natureza mundo.

\section{Resultados e Discussão}

Em relação a transformação do conhecimento geográfico renascentista, pode ser apontado, o nascimento do Estado Nacional, pois com o advento deste, há a concepção de fronteira territorial, conceituação discutida na obra $O$ Príncipe de Maquiavel (1469-1527), onde se discute também, o conceito de "fronteira móvel", em que o território de uma nação não se limita a um espaço físico, ele pode ser expandido através de zonas de influência, por meio de ações políticas e econômicas, para representar essas territorialidades é desenvolvida a Cartografia.

Para Crosby (1999) e Santos (2002) esta transformou o significado de natureza mundo, em relação ao tempo e espaço. As primeiras obras cartográficas conhecidas são as Cartas Portulanos, século XIII e XIV, a mais reconhecida é o Mapa Mundi de 1569 de Gerhard Mercator (1515-1594). Para Santos (2002), ela é a representação gráfica da realidade de mundo no princípio da Idade Moderna, sua confecção pode ser atribuída ao Mercantilismo burguês e as Grandes Navegações. Assim, ela rompe e amplia a concepção tempo e espaço medieval de mundo, filosófica teológica dos Mapas $T-O$, já que passam a ser representados quantitativamente.
Figura 1. Cartografia medieval

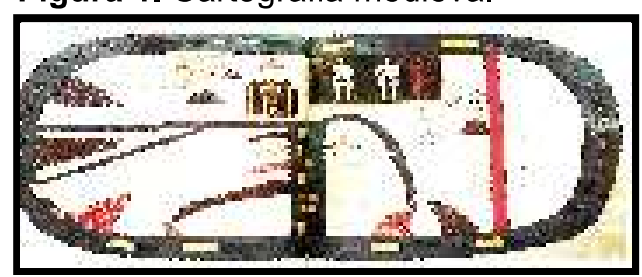

Mapa T-O. Fonte: SANTOS, 2002, p. 196-197.

Figura 2. Cartografia renascentista

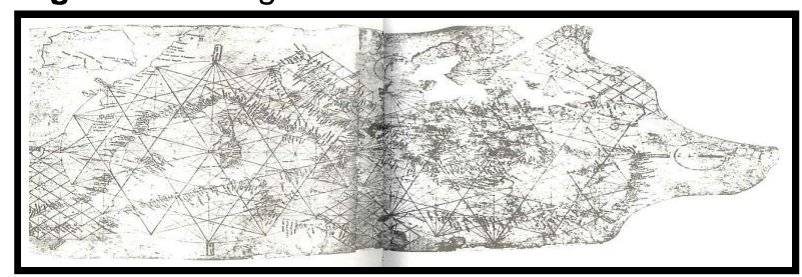

Carta Portulano. Fonte: SANTOS, 2002, p. 198-199.

Figura 3. Cartografia moderna

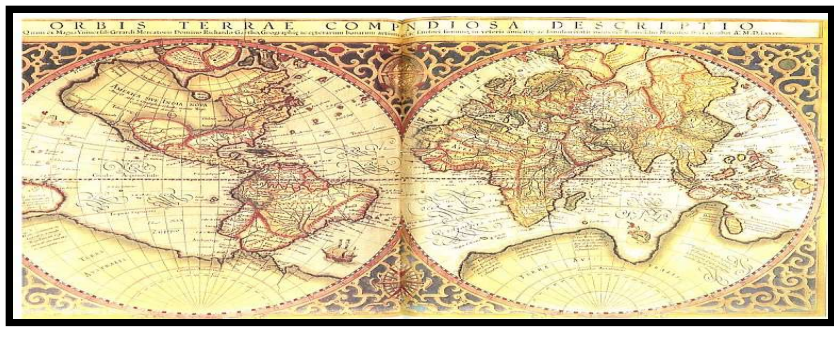

Cartografia Mercator. Fonte: SANTOS, 2002, p. 208-209.

Conclusões

Houve um avanço na concepção geográfica, tempo e espaço, saindo de visão medieval, filosófica teológica, para uma renascentista, visual e quantitativa, que passaram a ser representados graficamente e quantitativamente na cartografia moderna de mercator.

CROSBY, A. W. A mensuração da realidade: a quantificação e a sociedade ocidental, 1250-1600. Tradução de Vera Ribeiro. São Paulo: Editora UNESP, 1999

DEBUS, A. G. O Homem e a Natureza no Renascimento. Tradução de Fernando Magalhães. Portugal: Porto Editora, 2002.

ROSA, A. P. História da Ciência: Da Antiguidade ao Renascimento Científico. Brasília: Fundação Alexandre Gusmão, 2010. v. 1

SANTOS, D. A reinvenção do espaço: diálogos em torno da construção do significado de uma categoria. São Paulo: Editora UNESP, 2002. 